\title{
Maerua angolensis DC. (Capparaceae): A Review of its Medicinal Uses, Phytochemistry and Pharmacological Properties
}

\author{
Alfred Maroyi
}

\author{
Department of Botany, University of Fort Hare, Private Bag X1314, Alice 5700, South Africa
}

\begin{abstract}
Maerua angolensis DC. is collected from the wild for its edible leaves and fruits, and is also used as a traditional medicine. This study is aimed at evaluating the ethnomedicinal uses, phytochemistry and pharmacological properties of $M$. angolensis. Results of the current study are based on data derived from several online databases such as Scopus, Google Scholar, PubMed and Science Direct, and pre-electronic sources such as scientific publications, books, dissertations, book chapters and journal articles. The articles published between 1960 and 2020 were used in this study. This study revealed that the aerial parts, bark, leaves, roots and stem bark infusion and/or decoction of $M$. angolensis are mainly used as a protective charm and ethnoveterinary medicine, and a traditional medicine for pain, cancer, fever, malaria, sores, wounds and gastro-intestinal problems. Phytochemical compounds identified from the species include alkaloids, amino acids, anthraquinones, betaines, cardiac glycosides, cyanidin, esters, fatty acids, flavonoids, glucosinolates, phenols, saponins, sterols, steroids, tannins and triperpenoids. Ethnopharmacological research revealed that $M$. angolensis extracts have acaricidal, anthelmintic, antibacterial, antifungal, antidiarrhoeal, anticonvulsant, anti-diabetic, antidepressant, anti-inflammatory, antioxidant, antinociceptive, anxiolytic, anti-urolithiatic, antiprotozoal, molluscicidal and nematicidal activities. There is need for extensive toxicological evaluations of crude extracts and compounds isolated from the species since $M$. angolensis contains potentially toxic compounds
\end{abstract}

Keywords: Capparaceae, indigenous pharmacopeia, Maerua angolensis, traditional medicine.

\section{INTRODUCTION}

Maerua angolensis DC. is a deciduous tree belonging to the Capparaceae or caper family. The genus name "Maerua" means "drooping" in reference to the drooping foliage [1]. The specific epithet "angolensis" implies that the type specimen of the species came from Angola [2]. The English common name of $M$. angolensis is "bead bean" or "bushveld bead-bean" or "long bead bean" $[3,4]$. Synonyms associated with the name $M$. angolensis include $M$. arenicola sensu Eyles, M. bukobensis Gilg \& Gilg-Ben., M. currorii Hook. f., M. emarginata Schinz, M. lucida Hochst. ex A. Rich., M. retusa Hochst. ex A. Rich., $M$. senegalensis $\mathrm{R}$. $\mathrm{Br}$., $M$. thomsonii $\mathrm{T}$. Anderson and $M$. tomentosa Pax. [5-7]. Maerua angolensis is a small to medium-sized and rounded tree which can grow up to 10 metres in height $[4,8]$. The bark on young stems is purplish to yellowish in colour with light grey corky lenticels, and smooth and grey to rough and dark grey, peeling off in small flakes on older stems [1]. The leaves of $M$. angolensis are simple, entire, alternate, elliptic to lanceolate in shape, dark green and glossy, and the surface is covered in short hairs. The flowers are axillary and solitary, borne in terminal spikes or clusters and sweetly scented, with whitish to pink stamens. The fruit is a non-splitting pseudo-pod that is

${ }^{*}$ Address correspondence to this author at the Department of Botany, University of Fort Hare, Private Bag X1314, Alice 5700, South Africa; Tel/Fax: +27406022322; E-mail: amaroyi@ufh.ac.za irregularly constricted between the seeds. Maerua angolensis has been recorded in various types of woodland, wooded grassland, deciduous bushland, evergreen scrub, arid bushveld, termitaria, coastal thicket and fringing seasonal watercourses. The species is widespread in tropical Africa, from Senegal in the west, eastwards to Ethiopia and Kenya, through the Democratic Republic of Congo (DRC) southwards to Mozambique, Namibia and South Africa, mostly growing on sandy, loamy and rocky soils at an altitude ranging from sea level to $1700 \mathrm{~m}$ above sea level [511].

The fruits and leaves of $M$. angolensis are considered edible throughout the distributional range of the species [12-20]. The fruits and leaves of $M$. angolensis are also browsed by game and livestock [21-28]. This species is also used as an ornamental plant, live fence, hedge, shade and bee forage $[1,4,29,30]$. The bark and roots of $H$. angolensis are sold in informal herbal medicine markets as traditional medicine in Tanzania [31] and dried leaves are also traded in local markets as a leafy vegetable and famine food supplement [29]. But the fruits, leaves and roots of $M$. angolensis are regarded as poisonous $[2,3]$ and in Tanzania, the leaves are used as fish poison $[29,32,33]$ and the roots are sometimes used for homicidal purposes [32,34]. Thus, the aim of this review is to provide an integrated and detailed appraisal of the existing knowledge on the medicinal uses, phytochemistry and pharmacological properties of $M$. 
angolensis in an attempt to explore the therapeutic and functional potential of this species.

\section{Medicinal Uses}

The aerial parts, bark, leaves, roots and stem bark infusion and/or decoction of $M$. angolensis are mainly used as a protective charm and an ethnoveterinary medicine, and a traditional medicine for pain, cancer, fever, malaria, sores, wounds and gastro-intestinal problems (Table 1; Figure 1). Other medicinal applications recorded in at least two countries and supported by at least two literature reports include the use of bark, leaves, roots and stem bark infusion and/or decoction against convulsions, epilepsy, headache, jaundice, pregnancy disorders, purgative, sexually transmitted infections, gonorrhoea and skin problems (Table 1).

\section{Nutritional and Phytochemistry}

Some researchers identified nutritional elements and phytochemical compounds from the aerial parts, leaves, roots and stem bark of $M$. angolensis and these

Table 1: Medicinal Uses of Maerua angolensis

\begin{tabular}{|c|c|c|c|}
\hline Medicinal uses & Parts used & Country & Reference \\
\hline Abortifacient & Roots & Tanzania & [32] \\
\hline Anorexia & Leaves & Senegal & [29] \\
\hline Aphrodisiac & Leaves, roots and stem bark & Tanzania & {$[32,29]$} \\
\hline Asthenia & Leaves & Senegal & [29] \\
\hline Cancer (breast and skin) & Bark, leaves and stem bark & Nigeria, South Africa and Sudan & {$[1,21,35,36]$} \\
\hline Chest pains & Roots & Tanzania & [4] \\
\hline Convulsions and epilepsy & Bark, leaves, roots and stem bark & South Africa and Tanzania & {$[1,21,29,37]$} \\
\hline Fever and malaria & Leaves, roots and stem bark & $\begin{array}{c}\text { Burkina Faso, Sudan, Tanzania and } \\
\text { Yemeni }\end{array}$ & {$[29,31,38,39]$} \\
\hline $\begin{array}{l}\text { Gastro-intestinal problems (amoebic } \\
\text { dysentery, diarrhoea and stomach } \\
\text { ache) }\end{array}$ & Bark, leaves, roots and stem bark & $\begin{array}{l}\text { Benin, Burkina Faso, South Africa } \\
\text { and Tanzania }\end{array}$ & {$[1,19,21,29,37]$} \\
\hline General malaise & Leaves & Yemeni & [38] \\
\hline Headache & Leaves and roots & South Africa and Tanzania & {$[1,21,40]$} \\
\hline Hypertension & Leaves & Burkina Faso & [39] \\
\hline Influenza & Roots & Tanzania & {$[4,32,41]$} \\
\hline Jaundice & Leaves & Benin and Burkina Faso & {$[29,39]$} \\
\hline Lupus & Leaves & Tanzania & {$[32,34]$} \\
\hline Pain & Aerial parts and leaves & Guinea, Nigeria and Yemeni & {$[38,42,43]$} \\
\hline $\begin{array}{l}\text { Pregnancy disorders (lactation and } \\
\text { womb cleansing) }\end{array}$ & Leaves and roots & Botswana and Nigeria & [44-46] \\
\hline $\begin{array}{l}\text { Protective charm against lightning } \\
\text { and witchcraft }\end{array}$ & Bark, roots and stem bark & Botswana, South Africa and Tanzania & {$[31,47,48]$} \\
\hline Purgative & Bark, leaves, roots and stem bark & South Africa and Tanzania & $\begin{array}{c}{[1,21,32,34,37,4} \\
9]\end{array}$ \\
\hline $\begin{array}{l}\text { Sexually transmitted infections and } \\
\text { gonorrhoea }\end{array}$ & Roots & Botswana and Ethiopia & {$[44,50]$} \\
\hline Skin problems (abscess and rash) & Roots & Botswana and Tanzania & {$[32,44]$} \\
\hline Sores and wounds & Leaves, roots and stem bark & Botswana, Kenya, Mali and Tanzania & {$[23,32,44,51]$} \\
\hline Toothache & Roots & Tanzania & {$[4,32,41]$} \\
\hline Urolithiasis & Leaves & Eritrea & {$[52]$} \\
\hline $\begin{array}{c}\text { Ethnoveterinary medicine } \\
\text { (anthelmintic, anthrax, bloat, } \\
\text { infertility, mastitis, pneumonia and } \\
\text { wounds) }\end{array}$ & Leaves, roots and stem bark & $\begin{array}{l}\text { Ethiopia, Nigeria, South Africa and } \\
\text { Sudan }\end{array}$ & [53-59] \\
\hline
\end{tabular}




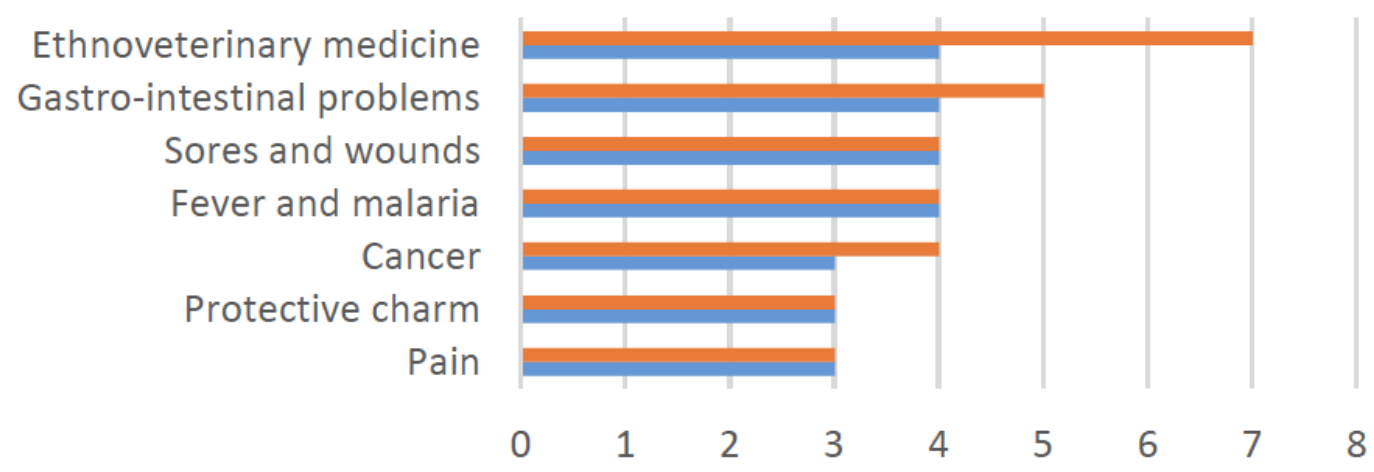

Literature records No. of countries

Figure 1: Medicinal applications of Maerua angolensis derived from literature records.

Table 2: Nutritional and Phytochemical Composition of Maerua angolensis

\begin{tabular}{|c|c|c|c|}
\hline 3-hydroxyprolinebetaine & - & Leaves & [79] \\
\hline Acid detergent fibre ( $\mathrm{g} / \mathrm{kg}$ dry matter) & $128.3-321.0$ & Leaves & {$[24,25,26]$} \\
\hline Acid detergent lignin (g/kg dry matter) & $56.4-969.0$ & Leaves & {$[24,25,26]$} \\
\hline Anthraquinones $(\mathrm{mg} / 100 \mathrm{~g})$ & 167.9 & Stem bark & [68] \\
\hline Arsenic $(\mu \mathrm{g} / \mathrm{g})$ & 0.2 & Roots & [44] \\
\hline Ash (\%) & $12.9-13.3$ & Leaves and stem bark & {$[16,68]$} \\
\hline Calcium (mg/100g) & 4786.0 & Leaves & [16] \\
\hline Cobalt $(\mathrm{mg} / \mathrm{kg})$ & 2.5 & Leaves & [25] \\
\hline Condensed tannin $(\mathrm{g} / \mathrm{kg})$ & 0.4 & Leaves & [26] \\
\hline Copper (mg/100g) & 4.7 & Leaves & [16] \\
\hline Crude fibre $(\%)$ & $15.0-48.5$ & Leaves and stem bark & {$[16,68]$} \\
\hline Crude oil (\%) & $3.1-6.3$ & Leaves and stem bark & {$[16,68]$} \\
\hline Crude protein (\%) & $21.8-33.2$ & Leaves and stem bark & {$[16,68]$} \\
\hline Cyanidins (g/kg dry matter) & 0.03 & Leaves & [24] \\
\hline Dodecanoic acid & - & Aerial parts & [29] \\
\hline Manganese $(\mathrm{mg} / 100 \mathrm{~g})$ & 1.9 & Leaves & [16] \\
\hline Moisture content (\%) & $3.6-7.9$ & Leaves and stem bark & {$[16,68]$} \\
\hline
\end{tabular}


(Table 2). Continued.

\begin{tabular}{|c|c|c|c|}
\hline Nutritional and chemical compound & Value & Plant part & Reference \\
\hline Molybdenum (mg/kg) & 25.8 & Leaves & {$[25]$} \\
\hline Neutral detergent fibre ( $\mathrm{g} / \mathrm{kg}$ dry matter) & $190.2-586.7$ & Leaves & {$[24,25,26]$} \\
\hline Octadecanoic acid & - & Aerial parts & {$[29]$} \\
\hline Organic matter (\%) & 86.7 & Stem bark & {$[68]$} \\
\hline Phenol (mg/100g dry weight) & 2.0 & Leaves & {$[16]$} \\
\hline Phosphorus (mg/100g) & 205.1 & Leaves & {$[16]$} \\
\hline Potassium (mg/100g) & 832.2 & Leaves & {$[16]$} \\
\hline Prolinebetaine & - & Leaves & {$[79]$} \\
\hline Reducing sugars (mg/100g) & 41.2 & Stem bark & {$[68]$} \\
\hline Saponins (mg/100g) & 225.6 & Stem bark & {$[68]$} \\
\hline Selenium (mg/kg) & 19.5 & Leaves & {$[25]$} \\
\hline Sodium (mg/100g) & 96.1 & Leaves & [16] \\
\hline Steroids (mg/100g) & 112.3 & Stem bark & {$[68]$} \\
\hline Sulfur $(g / k g)$ & 2.1 & Leaves & {$[25]$} \\
\hline Tannin $(\mathrm{mg} / 100 \mathrm{~g})$ & $17.2-340.3$ & Leaves and stem bark & {$[16,68]$} \\
\hline Tetradecanoic acid & - & Aerial parts & {$[29]$} \\
\hline Total flavonoids (mg QE/g of fraction) & $0.9-12.0$ & Leaves and stem bark & {$[80,81]$} \\
\hline Total extractable phenolics (g/kg dry matter) & $10.0-11.4$ & Leaves & {$[24,25]$} \\
\hline Total condensed tannins ( $\mathrm{g} / \mathrm{kg}$ dry matter) & $0.03-3.4$ & Leaves & {$[24,25]$} \\
\hline Vitamin C (mg/100g) & 3.9 & Leaves & {$[16]$} \\
\hline Zinc (mg/100g) & 3.2 & Leaves & {$[16]$} \\
\hline
\end{tabular}

include alkaloids, anthraquinones, betaines, cyanidin, fatty acids, flavonoids, phenolics, tannins, nutritional compounds, minor and major elements (Table 2). Other phytochemical compounds identified from the leaves and stem bark of $M$. angolensis include amino acids, cardiac glycosides, esters, glucosinolates, phenols, resins, saponins, sterols, steroids, terpenoids and triperpenoids [52,60-68].

\section{Pharmacological Properties}

The following pharmacological activities have been documented from the fruits, leaves, stems and stem bark of $M$. angolensis: acaricidal, anthelmintic, antibacterial, antifungal, antidiarrhoeal, anticonvulsant, anti-diabetic, antidepressant, anti-inflammatory, antioxidant, antinociceptive, anxiolytic, anti-urolithiatic, antiprotozoal, molluscicidal and nematicidal activities.

\section{Acaricidal Activities}

Fouche et al. [58] evaluated the acaricidal activities of acetone and ethanol extracts of $M$. angolensis leaves and stems against tick species; Rhipicephalus microplus and Rhipicephalus turanicus using the Shaw larval and adult immersion test. The ethanol leaf extract exhibited $100.0 \%$ mortality against Rhipicephalus microplus while acetone leaf extract exhibited $100.0 \%$ mortality against Rhipicephalus turanicus [58].

\section{Anthelmintic Activities}

Fouche et al. [56] evaluated the anthelmintic activities of acetone extracts of $M$. angolensis leaves and stems against Haemonchus contortus using the egg hatch assay with albendazole as a positive control. The stem extract exhibited the best activities of $65.0 \%$ at a concentration of $2.5 \mathrm{mg} / \mathrm{mL}$ against $100.0 \%$ exhibited by the positive control [56].

\section{Antibacterial Activities}

Mothana et al. [65] evaluated the antibacterial activities of methanol and hot aqueous extracts of $\mathrm{M}$. angolensis leaves against Staphylococcus aureus, Bacillus subtilis, Micrococuss flavus, Escherichia coli, Pseudomonas aeruginosa, Staphylococcus epidermidis 
and Staphylococcus haemolyticus using agar diffusion method and broth micro-dilution assay with ampicillin $(10.0 \mu \mathrm{g} / \mathrm{disc})$ and gentamicin $(10.0 \mu \mathrm{g} / \mathrm{disc})$ as positive controls. The hot aqueous extract exhibited activities against Staphylococcus aureus and Staphylococcus epidermidis with zone of inhibition values of $16.0 \mathrm{~mm}$ and $12.0 \mathrm{~mm}$, respectively. The minimum inhibitory concentration (MIC) values against Staphylococcus aureus, Bacillus subtilis and Micrococuss flavus were $>1000.0 \mu \mathrm{g} / \mathrm{ml}$ [65]. Ayo et al. [66] evaluated the antibacterial activities of methanol and petroleum ether extracts of $M$. angolensis leaves against Staphylococcus aureus, Streptococcus pyogenes, Corynebacterium ulcerans, Bacillus subtilis, Escherichia coli, Salmonella typhi, Klebsiella pneumoniae, Pseudomonas aeruginosa and Neisseria gonorrhoeae using agar diffusion and micro dilution methods with sparfloxacin $(30.0 \mu \mathrm{g} / \mathrm{ml})$ as a positive control. The petroleum ether extract exhibited activities against Bacillus subtilis only while methanol extract exhibited activities against all of the tested pathogens with the zone of inhibition ranging from $10.0 \mathrm{~mm}$ to $22.0 \mathrm{~mm}$ against $35.0 \mathrm{~mm}$ to $45.0 \mathrm{~mm}$ exhibited by the positive control, and the MIC values ranged from 6.3 $\mathrm{mg} / \mathrm{ml}$ to $25.0 \mathrm{mg} / \mathrm{ml}$ [66]. Yusuf et al. [67] evaluated the antibacterial activities of n-hexane, chloroform, water, ethyl acetate and methanol fractions of $M$. angolensis leaves against Staphylococcus aureus and Escherischia coli using the agar diffusion assay with ciprofloxacin as a positive control. All the fractions except water fraction exhibited activities with the zone of inhibition ranging from $9.0 \mathrm{~mm}$ to $16.0 \mathrm{~mm}$ against $22.0 \mathrm{~mm}$ to $30.0 \mathrm{~mm}$ exhibited by the positive control [67].

\section{Antifungal Activities}

Khan [60] evaluated the antifungal activities of petrol, ether and chloroform extracts of $M$. angolensis bark against Trichophyton mentagrophytes and Candida albicans using the agar diffusion assay with clotrimazole $(50.0 \mu \mathrm{g})$, ketoconazole $(50.0 \mu \mathrm{g})$ and nystatin $(100.0 \mu \mathrm{g})$ as positive controls. The ether and chloroform extracts exhibited activities against Trichophyton mentagrophytes with the zone of inhibition values of $20.0 \mathrm{~mm}$ to $25.0 \mathrm{~mm}$ [60]. Ayo et al. [66] evaluated the antifungal activities of methanol and petroleum ether extracts of $M$. angolensis leaves against Candida albicans using agar diffusion and micro dilution methods with fluconazole $(30.0 \mu \mathrm{g} / \mathrm{ml})$ as a positive control. The methanol extract exhibited activities against the tested pathogen with the zone of inhibition of $17.0 \mathrm{~mm}$ in comparison to the zone of inhibition of $37.0 \mathrm{~mm}$ exhibited by the positive control and a MIC value of $12.5 \mathrm{mg} / \mathrm{ml}$ [66].

\section{Antidiarrhoeal Activities}

Magaji et al. [62] evaluated the antidiarrhoeal activities of the aqueous methanolic stem bark extract of $M$. angolensis using castor oil-induced diarrhoeal model in mice with loperamide as a positive control. The extract protected $80.0 \%$ of the mice at a dosage of $400.0 \mathrm{mg} / \mathrm{kg}$ compared to $100.0 \%$ exhibited by the positive control [62].

\section{Anticonvulsant Activities}

Magaji et al. [63] evaluated the anticonvulsant activities of hydroalcoholic extract of the stem bark of M. angolensis at doses of 200.0, 400.0 and 800.0 $\mathrm{mg} / \mathrm{kg}$ in experimental animal models using maximal electroshock test, pentylenetetrazole and 4aminopyridine-induced seizures, diazepam-induced sleep, hole board, and beam walking tests. Fifty percent of the chicks and $40.0 \%$ of the mice were protected against maximal electroshock test and 4aminopyridine-induced seizure at the dosage of 400.0 $\mathrm{mg} / \mathrm{kg}$, respectively. In the pentylenetetrazole-induced seizure, $33.0 \%$ of the mice were protected at the dosage of $800.0 \mathrm{mg} / \mathrm{kg}$. The extract reduced the mean number of head-dips in the exploratory test, shortened the onset and prolonged the duration of diazepam induced sleep at the dosage of $800.0 \mathrm{mg} / \mathrm{kg}$ [63]. Benneh et al. [72] evaluated the anticonvulsant activities of petroleum ether: ethyl acetate (50:50) extract of $M$. angolensis stem bark at doses ranging from $100.0 \mathrm{mg} / \mathrm{kg}$ to $1000.0 \mathrm{mg} / \mathrm{kg}$ were administered per os to male Sprague-Dawley rats after pre-treatment with flumazenil $(0.3 \mathrm{mg} / \mathrm{kg})$ or L-arginine $(150.0 \mathrm{mg} / \mathrm{kg})$ or sildenafil $(5.0 \mathrm{mg} / \mathrm{kg} 1)$ and subcutaneous injection of pentylenetetrazole $(65.0 \mathrm{mg} / \mathrm{kg})$. The extract exhibited antiseizure activities by affecting the GABAergic and nitric oxide-cGMP pathways [72]

\section{Anti-Diabetic Activities}

Mohammed et al. [64] evaluated the anti-diabetic activities of aqueous methanolic extracts of $M$. angolensis stem bark in streptozocin-induced diabetic rats at doses of $250.0 \mathrm{mg} / \mathrm{kg}, 500.0 \mathrm{mg} / \mathrm{kg}$ and 1000.0 $\mathrm{mg} / \mathrm{kg}$. The extract caused a reduction in the blood glucose levels [64].

\section{Antidepressant Activities}

Benneh et al. [73] evaluated the antidepressant activities of the petroleum ether: ethyl acetate (50:50) 
extract of $M$. angolensis stem bark using the forced swim and tail suspension tests in mice at doses of the extract ranging from $100.0 \mathrm{mg} / \mathrm{kg}$ to $1000.0 \mathrm{mg} / \mathrm{kg}$. The extract resulted in a reduction in immobility duration in the forced swim test at $300.0 \mathrm{mg} / \mathrm{kg}$ and tail suspension test at $1000.0 \mathrm{mg} / \mathrm{kg}$ [73].

\section{Anti-Inflammatory Activities}

Adamu et al. [61] evaluated the anti-inflammatory activities of aqueous methanolic extract of $M$. angolensis stem bark using carrageenan-induced hind paw oedema and cotton pellet granuloma models in rats. The extract exhibited dose-dependent activities in carrageenan-induced oedema in rats while in the granuloma pouch, the extract exhibited a $52.3 \%$ reduction in granuloma weight at the dose of 500.0 $\mathrm{mg} / \mathrm{kg}$ [61]. Ampadu et al. [74] evaluated the acute antiinflammatory activities of of petroleum ether: ethyl acetate extract of $M$. angolensis stem bark in acute inflammatory models. The anti-inflammatory activities of the extract at doses ranging from $30.0 \mathrm{mg} / \mathrm{kg}$ to $300.0 \mathrm{mg} / \mathrm{kg}$ were assessed on neutrophil infiltration, exudate volume, endogenous antioxidant enzymes in lung tissues and lung morphology using the carrageenan induced pleurisy model in Sprague Dawley rats. The extract exhibited anti-inflammatory activities by attenuating carrageenan induced pleurisy and decreasing acetic acid-induced vascular permeability [74].

\section{Antioxidant Activities}

Mothana et al. [65] evaluated the antioxidant activities of the methanol and hot aqueous extracts of $M$. angolensis using the 2,2-diphenyl-1-picrylhydrazyl (DPPH) free radical scavenging assay with ascorbic acid as a positive control. The methanol and hot aqueous extracts exhibited activities of $82.3 \%$ and $73.9 \%$, respectively, at a concentration of $50.0 \mu \mathrm{g} / \mathrm{ml}$ [65]. Meda et al. [70] evaluated the antioxidant activities of $\mathrm{n}$-hexane, dichloromethane, acetonitrile, ethyl acetate, methanolic and $n$-butanol fractions of $M$. angolensis leaves using the 2,2'-azinobis-3ethylbenzothiazoline-6-sulphonate (ABTS), DPPH and ferric reducing antioxidant power (FRAP) assays. The extracts exhibited activities with FRAP values ranging from $150.7-450.0 \mu \mathrm{mol}$ AAEAC/g of fraction, ABTS $(22.9-117.9 \mu \mathrm{mol}$ TEAC/g of fraction) and DPPH (3.8 $-81.1 \mu \mathrm{mol}$ QEAC/ $\mathrm{g}$ of fraction) [70].

\section{Antinociceptive Activities}

lliya et al. [75] evaluated the antinociceptive activities of the petroleum ether, ethyl acetate and hydroethanol extracts of $M$. angolensis stem bark in the formalin test in rats with diclofenac and morphine as reference analgesic agents and saline as a positive control. All the extracts exhibited antinociceptive activities by dose-dependently reducing the frequency and time spent in biting or licking of injected paws in both the neurogenic and inflammatory phases induced by formalin [75]. Iliya and Woode [76] evaluated the antinociceptive activities of petroleum ether and ethyl acetate extracts of $M$. angolensis stem bark using the acetic acid-induced abdominal writhing, formalininduced nociception, prostaglandin E2-induced mechanical hyperalgesia, bradykinin and epinephrineinduced thermal hyperalgesia tests, and Paw withdrawal test in rats. The extracts produced dosedependent activities in the acetic acid, formalin, prostaglandin E2, bradykinin, epinephrine and paw withdrawal tests [76]. Iliya et al. [77] evaluated the antinociceptive activities of the petroleum ether and ethyl acetate extract of $M$. angolensis stem bark in the vincristine-induced neuropathic pain model. The extract produced dose-dependent inhibition of vincristineinduced mechanical hyperalgesia, tactile and cold allodynia responses [77]. Iliya et al. [78] evaluated the antinociceptive activities of the petroleum ether : ethyl acetate extract of $M$. angolensis stem bark in the mouse tail-flick test using Hargreaves thermal hyperalgesia model. The extract administered orally at doses ranging from 3.0 to $30.0 \mathrm{mg} / \mathrm{kg}$ caused dose dependent attenuated nociception in the tail-flick test and possesses central analgesic effect, and suppressed morphine withdrawal syndrome via stimulation of GABA and adenosinergic transmission [78].

\section{Anxiolytic Activities}

Malami et al. [71] evaluated the the anxiolytic activities of hydromethanolic stem bark extract of $M$. angolensis using an animal model by conducting elevated plus maze and diazepam-induced sleeping time tests. The extract showed anxiolytic and sedative properties that exerted their effect on $\mathrm{GABA}_{\mathrm{A}}$ receptors [71]. Benneh et al. [79] evaluated the anxiolytic activities of petroleum ether : ethyl acetate fraction stem bark extract of $M$. angolensis and its possible mechanisms using zebrafish anxiety models. The extract demonstrated anxiolytic activities which could be a result of an interaction with the serotoninergic system and the $\mathrm{GABA}_{\mathrm{A}}$ receptor [79]. Benneh et al. [73] evaluated the the anxiolytic activities of petroleum ether: ethyl acetate (50:50) extract of $M$. angolensis stem bark using the Irwin, activity meter, convulsive 
threshold, pentobarbitone induced sleeping time, regular Suok and elevated plus-maze tests in mice models. The extract demonstrated anxiolytic activities in mice [73].

\section{Anti-Urolithiatic Activities}

Solomon et al. [52] evaluated the in vitro antiurolithiatic activities of aqueous, chloroform and ethanol extracts of $M$. angolensis leaves using turbidometric and titrimetric methods, and aggregation, growth and nucleation assays with cystone $(10.0 \mathrm{mg} / \mathrm{ml}$ and $20.0 \mathrm{mg} / \mathrm{ml}$ ) as the standard drug. The extracts exhibited inhibitory effects on calcium oxalate for crystal nucleation, aggregation and crystal growth, and dissolution of calcium oxalate crystals [52].

\section{Antiprotozoal Activities}

Kyere-Davies et al. [80] evaluated the antiprotozoal activities of ethanol extract of $M$. angolensis bark against Giardia lamblia using the in vitro susceptibility assay with metronidazole as a positive control. The extract exhibited activities with half maximal inhibitory concentration $\left(\mathrm{IC}_{50}\right)$ value of $20.0 \mu \mathrm{g} / \mathrm{mL}$ in comparison to an $\mathrm{IC}_{50}$ value of $10.5 \mu \mathrm{M}$ exhibited by the positive control [80].

\section{Molluscicidal Activities}

Cepleanu et al. [81] evaluated the in vitro molluscicidal activities of aqueous, dichloromethane and methanol extracts of $M$. angolensis fruits, leaves and stem bark against Biomphalaria glabrata snails. Only aqueous stem bark extract exhibited activities [81].

\section{Nematicidal Activities}

Khosa et al. [82] evaluated the nematicidal activities of crudely milled powders of $M$. angolensis leaves on eggs and infective second-stage juveniles population densities of Meloidogyne incognita race 2 on tomato (Solanum lycopersicum L.), which was examined under glasshouse conditions. The extract showed suppressive effect on the tested pathogen [82].

\section{Toxicity Activities}

Cepleanu et al. [91] evaluated the toxicity activities of aqueous, dichloromethane and methanol extracts of $M$. angolensis fruits, leaves and stem bark against Artemia salina cysts using the brine shrimp toxicity assay. The dichloromethane extract of the fruits exhibited activities with median lethal concentration
$\left(\mathrm{LC}_{50}\right)$ value of $8.7 \mu \mathrm{g} / \mathrm{ml}$ [91]. Fouche et al. [83] evaluated the toxicity of hot water and hydroethanolic (70:30) extracts of $M$. angolensis on Vero African Green monkey kidney cells and HepG2 human liver cancer cells using the tetrazolium-based (MTT) colorimetric assay with doxorubicin hydrochloride (Pfizer) as a positive control. The hydroethanolic extract exhibited a $L_{50}$ value of $27.0 \mu \mathrm{g} / \mathrm{mL}$ in comparison to a $\mathrm{LC}_{50}$ value of $1.5 \mu \mathrm{g} / \mathrm{mL}$ exhibited by the positive control [83].

\section{CONCLUSION}

Maerua angolensis is known to be poisonous $[2,3,29,32-34]$ and there is a need for detailed clinical and toxicological evaluations of crude extracts and compounds isolated from the species. Therefore, the widespread use of $M$. angolensis as food plant and source of traditional medicines throughout its distributional range suggest that the species is not taken at toxic dosages. But the use of $M$. angolensis as food and for the treatment of human diseases and ailments should be treated with caution and rigorous toxicological and clinical studies of the bark, fruits, leaves and roots, and compounds isolated from the species are necessary.

\section{CONFLICT OF INTEREST}

No conflict of interest is associated with this work.

\section{REFERENCES}

[1] Venter F, Venter J-A. Making the most of indigenous trees. Pretoria: Briza Publications; 2015.

[2] Palmer E, Pitman N. Trees of southern Africa covering all known indigenous species in the Republic of South Africa, South-West Africa, Botswana, Lesotho and Swaziland. Cape Town: AA Balkema; 1972

[3] Schmidt E, Lotter M, McCleland W. Trees and shrubs of Mpumalanga and Kruger National Park. Johannesburg: Jacana Media; 2017

[4] Dharani N. Field guide to common trees and shrubs of East Africa. Cape Town: Struik Nature; 2019.

[5] Wild H. Capparidaceae. In Exell AW, Wild H (Eds.), Flora Zambesiaca 1. London: Crown Agents for Oversea Governments and Administrations; 1960, pp. 194-245.

[6] Elfers RA, Grahama DG, Dewolf P. Capparidaceae. In Hubbard CE, Milne-Redhead E (Eds.), Flora of Tropical East Africa. London: Crown Agents for Oversea Governments and Administrations; 1964, pp. 1-88.

[7] Kers LE. Capparidaceae (Capparaceae). In Edwards S, et al (Eds.), Flora of Ethiopia and Eritrea vol. 2(1). Uppsala: Swedish Science Press; 2000, pp. 74-120.

[8] Palgrave MC. Keith Coates Palgrave trees of southern Africa. Cape Town: Struik Publishers; 2002.

[9] Germishuizen G, Meyer NL. Plants of southern Africa: An annotated checklist. Pretoria: Strelitzia 14, National Botanical Institute; 2003. 
[10] Figueiredo E, Smith GF. Plants of Angola. Pretoria: Strelitzia 22, South African National Biodiversity Institute; 2008.

[11] Van Wyk B, Van Wyk P. Field guide to trees of southern Africa. Cape Town: Struik Nature; 2013.

[12] Burkill HM. The useful plants of west tropical Africa. Richmond: Royal Botanical Garden, Kew; 1985.

[13] Peters CR, O'Brien EM, Drummond RB. Edible wild plants of sub-Saharan Africa. Richmond: Royal Botanic Gardens, Kew; 1992.

[14] Achigan-Dako EG, et al. Traditional vegetables in Benin: Diversity, distribution, ecology, agronomy and utilization. Porto-Novo: Institute National des Recherches Agricoles; 2010.

[15] Teketay D, et al. Edible wild plants in Ethiopia. Addis Ababa: Addis Ababa University Press; 2010.

[16] Tairo VE, et al. Nutritive and anti-nutritive qualities of mostly preferred edible woody plants in selected drylands of Iringa district, Tanzania. Pakistan J Nutr 2011; 10: 786-91. https://doi.org/10.3923/pjn.2011.786.791

[17] Addis G, Asfaw Z, Woldu Z. The role of wild and semi-wild edible plants in household food sovereignty in Hamer and Konso communities, south Ethiopia. Ethnobot Res Appl 2013; 11: 251-71.

[18] Ojelel S, et al. Wild edible plants used by communities in and around selected forest reserves of Teso-Karamoja region, Uganda. J Ethnobiol Ethnomed 2019; 15: 3. https://doi.org/10.1186/s13002-018-0278-8

[19] Ramde-Tiendrebeogo A, et al. Menopause disorders and their treatment in traditional medicine in Burkina Faso. J Med Plants Res 2019; 13(18): 458-72. https://doi.org/10.5897/JMPR2019.6844

[20] Welcome AK, Van Wyk B-E. An inventory and analysis of the food plants of southern Africa. S Afr J Bot 2019; 122: 136-79. https://doi.org/10.1016/j.sajb.2018.11.003

[21] Mabogo DEN. Ethnobotany of the Vhavenda. MSc Dissertation. Pretoria: University of Pretoria; 1990.

[22] Stilles D, Kassam A. An ethnobotanical study of Gabra plant use in Marsabit district, Kenya. J East Afr Nat History Soc Nat Museum 1991; 81: 14-37.

[23] Bussmann RW. Ethnobotany of the Samburu of Mt. Nyiru, South Turkana, Kenya. J Ethnobiol Ethnomed 2006; 2: 35. https://doi.org/10.1186/1746-4269-2-35

[24] Osuga IM, et al. Potential nutritive value of selected browse species from Kenya using in vitro gas production technique and polyethylene glycol. Livestock Res Rural Develop 2006; 18: 12.

[25] Ondiek J, Abdulrazak S, Njoka E. Chemical and mineral composition, in-vitro gas production, in-sacco degradation of selected indigenous Kenyan browses. Livestock Res Rural Develop 2010; 22: 2.

[26] Njidda AA, Olatunji EA, Garba MG. In sacco and in vitro organic matter degradability (OMD) of selected semi arid browse forages. IOSR J Agr Vet Sci 2013; 3(2): 9-16. https://doi.org/10.9790/2380-0320916

[27] Ouédraogo $\mathrm{P}$, et al. Uses and vulnerability of ligneous species exploited by local population of northern Burkina Faso in their adaptation strategies to changing environments. Agr Food Sec 2017; 6: 15. https://doi.org/10.1186/s40066-017-0090-z

[28] Salamula JB, et al. Camel forage variety in the Karamoja subregion, Uganda. Pastoralism Res Policy Pract 2017; 7: 8. https://doi.org/10.1186/s13570-017-0080-6

[29] El-Kamali HH. Maerua angolensis DC. In Schmelzer GH, Gurib-Fakim A (Eds.), Plant resources of tropical Africa 11(2): Medicinal plants 2. Wageningen: Backhuys Publishers; 2013, pp. 160-2.
[30]

Tshisikhawe MP, Malunga G. Ethnobotanical profile of indigenous tree species protected within dryland agricultural farming system. Res Reviews J Agr Allied Sci 2017; 6(2): 1521.

[31] Hilonga $S$, et al. Trade of wild-harvested medicinal plant species in local markets of Tanzania and its implications for conservation. S Afr J Bot 2019; 122: 214-24. https://doi.org/10.1016/j.sajb.2018.08.012

[32] Hedberg I, et al. Inventory of plants used in traditional medicine in Tanzania. I. Plants of the families AcanthaceaeCucurbitaceae. J Ethnopharmacol 1982; 6: 29-60. https://doi.org/10.1016/0378-8741(82)90070-8

[33] Neuwinger HD. Plants used for poison fishing in tropical Africa. Toxicon 2004; 44: 417-30. https://doi.org/10.1016/j.toxicon.2004.05.014

[34] Watt JM, Breyer-Brandwijk MG. The medicinal and poisonous plants of southern and eastern Africa. London: E. and S. Livingstone Ltd; 1962.

[35] Musa MS, et al. Ethnobotanical study of medicinal plants in the Blue Nile State, South-eastern Sudan. J Med Plants Res 2011; 5(17): 4287-97.

[36] Ngulde SI, Sandabe UK, Hussaini IM. Ethnobotanical survey of anticancer plants in Askira/Uba local government area of Borno State, Nigeria. Afr J Pharm Pharmacol 2015; 9(5): 123-30. https://doi.org/10.5897/AJPP2014.4083

[37] Chhabra SC, Mahunnah RLA, Mshiu EN. Plants used in traditional medicine in eastern Tanzania. II. Angiosperms (Capparidaceae to Ebenaceae). J Ethnopharmacol 1989; 25: 339-59. https://doi.org/10.1016/0378-8741(89)90038-X

[38] Miller GA, Morris M: Ethnoflora of the Soqotra Archipelago. Edinburgh: The Royal Botanic Garden; 2004.

[39] N'do JY-P, et al. Ethnobotany and preliminary bioactivity investigation on hepatoprotective medicinal plants from the Mouhoun region of Burkina Faso. Int J Phytomed 2018; 10(2): 73-80.

\section{https://doi.org/10.5138/09750185.2214}

[40] Ngowi NJ. Ethnobotanical study of medicinal plants in Kondoa eroded area of central Tanzania. Int J Sci Basic Appl Res 2015; 21(1): 223-33.

[41] Kokwaro JO. Medicinal plants of East Africa. Nairobi: University of Nairobi Press; 2009.

[42] Abubakar MS, et al. The perception and practice of traditional medicine in the treatment of cancers and inflammations by the Hausa and Fulani tribes of Northern Nigeria. J Ethnopharmacol 2007; 111: 625-9.

https://doi.org/10.1016/j.jep.2007.01.011

[43] Baldé AM, et al. Ethnobotanical survey, antimicrobial and anticomplement activities of Guinean medicinal plants traditionally used in the treatment of inflammatory diseases in Conakry and Dubreka. J Plant Sci 2015; 3: 11-19.

[44] Okatch $\mathrm{H}$, et al. Determination of potentially toxic heavy metals in traditionally used medicinal plants for HIVIAIDS opportunistic infections in Ngamiland district in northern Botswana. Analytica Chimica Acta 2012; 730: 42-8. https://doi.org/10.1016/j.aca.2011.11.067

[45] Danjuma MN, Darda'u H. An ethno-survey of medicinal trees of Kabobi village, northern Katsina, Nigeria. Academic Res Int 2013; 4(3): 174-83.

[46] Singh D. Study on traditional medicinal flora of Argungu local government areas, Kebbi State, Nigeria, west Africa. Int J Modern Plant Animal Sci 2015; 3(1): 16-32.

[47] Hedberg I, Staugård F. Traditional medicine in Botswana: Traditional medicinal plants. Gaborone: Ipelegeng Publishers; 1989

[48] Koopman A. Lightning birds and thunder trees. Natalia 2011; 41: $40-60$. 
[49] Liengme CA. Plants used by the Tsonga people of Gazankulu. Bothalia 1981; 13: 501-18. https://doi.org/10.4102/abc.v13i3/4.1357

[50] Wondimu T, Asfaw Z, Kelbessa E. Ethnobotanical study of medicinal plants around 'Dheeraa' town, Arsi Zone, Ethiopia. J Ethnopharmacol 2007; 112: 152-61. https://doi.org/10.1016/j.jep.2007.02.014

[51] Diallo D, et al. Wound healing plants in Mali, the Bamako region. An ethnobotanical survey and complement fixation of water extracts from selected plants. Pharmaceut Biol 2002; 40(2): 117-28.

https://doi.org/10.1076/phbi.40.2.117.5846

[52] Solomon A, et al. Antiurolithiatic activity of the leaf extracts of Maerua angolensis. Archives Pharm Pharmacol Res 2019; 2(2): 1-6.

[53] Giday M, Ameni G. An ethnobotanical survey on plants of veterinary importance in two woredas of southern Tigray, northern Ethiopia. Sinet Ethiopian J Sci 2003; 26(2): 123-36. https://doi.org/10.4314/sinet.v26i2.18208

[54] Khalid $\mathrm{H}$, et al. Gems from traditional north-African medicine: medicinal and aromatic plants from Sudan. Natural Prod Bioprospect 2012; 2: 92-103.

https://doi.org/10.1007/s13659-012-0015-2

[55] Luseba D, Tshisikhawe MP. Medicinal plants used in the treatment of livestock diseases in Vhembe region, Limpopo province, South Africa. J Med Plants Res 2013; 7(10): 593601.

[56] Fouche G, et al. Anthelmintic activity of acetone extracts from South African plants used on egg hatching of Haemonchus contortus. Onderstepoort J Vet Res 2016; 83(1): a1164. https://doi.org/10.4102/ojvr.v83i1.1164

[57] Usman IS. Ethno-veterinary care amongst the nomadic Fulani herdsmen in southern zone of Adamawa State, Nigeria. J Animal Sci Vet Med 2016; 1(4): 108-17. https://doi.org/10.31248/JASVM2016.038

[58] Fouche G, Eloff JN, Wellington K. Evaluation of South African plants with acaricide activity against ticks. Int $\mathrm{J}$ Pharmacol Pharmaceut Sci 2017; 11(6): 386-90.

[59] Gebeyew K, et al. Indigenous medicinal uses, toxicity, and chemical composition of browsing plant used by camel in Ethiopia Somali Regional State: A survey. Trop Animal Health Prod 2020; 52: 1459-66. https://doi.org/10.1007/s11250-019-02152-1

[60] Khan MR. Antimycoctic activity of some medicinal plants. Pharmaceut Biol 1999; 37(5): 346-50. https://doi.org/10.1076/phbi.37.5.346.6059

[61] Adamu A, et al. Effect of aqueous methanolic stem-bark extract of Maerua angolensis DC on acute and sub-acute inflammations. Nigerian J Pharmaceut Sci 2007; 6(2): 1-6.

[62] Magaji MG, et al. Preliminary gastro-intestinal studies on aqueous methanolic stem-bark extract of Maerua angolensis (Capparaceae). Nigerian J Pharmaceut Sci 2008; 7(1): 10813.

[63] Magaji MG, et al. Some neuropharmacological studies on hydroalcoholic extract of Maerua angolensis (Caparidaceae) in mice and chicks. Int J Pure Appl Sci 2009; 3: 14-21.

[64] Mohammed A, et al. Effects of aqueous methanolic stembark of Maerua angolensis (Capparidaceae) extract on blood glucose levels of streptozocin-induced diabetic Wistar rats. Res J Pharmacol 2008; 1(4): 75-8.

[65] Mothana RA, et al. Studies of the in vitro anticancer, antimicrobial and antioxidant potentials of selected Yemeni medicinal plants from the island Soqotra. BMC Compl Alt Med 2009; 9 : 7.

https://doi.org/10.1186/1472-6882-9-7

[66] Ayo RG, et al. Phytochemical screening and antimicrobial activity of three plants used in traditional medicine in Northern Nigeria. J Med Plants Res 2013; 7(5): 191-7.
[67] Yusuf AS, et al. Phytochemical screening and antibacterial activity of Acalypha wilkesiana and Maerua angolensis. J Pharmaceut Chem Biol Sci 2017; 5(2):103-7.

[68] Williams ET, Timothy N, Chika A. Phytochemical screening, elemental and proximate analysis of Maerua angolensis (Capparaceaea) stem bark. Int J Biochem Res Review 2019; 27(4): 1-10.

https://doi.org/10.9734/ijbcrr/2019/v27i430126

[69] McLean WFH, Blunden G, Jewers K. Quaternary ammonium compounds in the Capparaceae. Biochem Syst Ecol 1996; 24(5): 427-34.

https://doi.org/10.1016/0305-1978(96)00044-0

[70] Meda NTR, et al. Antioxidant activity of phenolic and flavonoid fractions of Cleome gynandra and Maerua angolensis of Burkina Faso. J Appl Pharmaceut Sci 2013; 3(2): 36-42.

https://doi.org/10.7324/JAPS.2013.30207

[71] Malami I, et al. Anxiolytic, sedative and toxicological effect of hydromethanolic stem bark extract of Maerua angolensis DC. in Wister rats. Pakistan J Pharmaceut Sci 2014; 27(5): 136370.

[72] Benneh CK, et al. Maerua angolensis DC. (Capparaceae) stem bark extract protects against pentylenetetrazoleinduced oxidative stress and seizures in rats. EvidenceBased Compl Alt Med 2018; article ID 9684138. https://doi.org/10.1155/2018/9684138

[73] Benneh CK, et al. Anxiolytic and antidepressant effects of Maerua angolensis DC. stem bark extract in mice. Depression Res Treatment 2018; article ID 1537371.

[74] Ampadu FA, et al. Antipleuritic and vascular permeability inhibition of the ethyl acetate-petroleum ether stem bark extract of Maerua angolensis DC (Capparaceae) in murine. Int J Inflammation 2018; article ID 6123094.

https://doi.org/10.1155/2018/6123094

[75] Iliya $\mathrm{H}$, et al. Antinociceptive activity of various solvent extracts of Maerua angolensis DC stem bark in rodents. Phytopharmacol 2014; 3(1): 1-8.

[76] Iliya HA, Woode E. Evaluation of analgesic property of petroleum ether/ethyl acetate stem bark extract and fractions of Maerua angolensis in murine models of pain. J Appl Pharmaceut Sci 2014; 5: 91-102.

\section{https://doi.org/10.7324/JAPS.2015.50214}

[77] Iliya HA, et al. Maerua angolensis extract reduces allodynia and hyperalgesia in a mouse model of vincristine-induced peripheral neuropathy. J Appl Pharmaceut Sci 2016; 6 (5): 124-30. https://doi.org/10.7324/JAPS.2016.60519

[78] Iliya $\mathrm{H}$, et al. Analgesic activity and effect of Maerua angolensis stem bark extract and fractions on morphine dependence in mice. Pharma Innov J 2015; 4(2): 62-8.

[79] Benneh CK, et al. Maerua angolensis stem bark extract reverses anxiety and related behaviours in zebrafish: Involvement of GABAergic and 5-HT systems. J Ethnopharmacol 2017; 207: 129-45. https://doi.org/10.1016/j.jep.2017.06.012

[80] Kyere-Davies G, et al. In vitro activity of selected Ghanaian medicinal plants against parasites: Giardia lamblia, Entamoeba histolytica and Naegleria fowleri. Afr J Pharm Pharmacol 2017; 11(23): 279-83. https://doi.org/10.5897/AJPP2017.4795

[81] Cepleanu $F$, et al. Screening of tropical medicinal plants for molluscicidal, larvicidal, fungicidal and cytotoxic activities and brine shrimp toxicity. Int J Pharmacog 1994; 32: 294-307. https://doi.org/10.3109/13880209409083007

[82] Khosa MC, et al. Examine medicinal plants from South Africa for suppression of Meloidogyne incognita under glasshouse conditions. J Nematol 2020; 52: e2020-29. https://doi.org/10.21307/jofnem-2020-029 
[83] Fouche G, et al. Acaricidal activity of the aqueous and hydroethanolic extracts of 15 South African plants against Rhipicephalus turanicus and their toxicity on human liver and kidney cells. Onderstepoort J Vet Res 2019; 86(1): a1665. https://doi.org/10.4102/ojvr.v86i1.1665

Received on 26-07-2020

Accepted on 21-09-2020

Published on $15-10-2020$

DOI: https://doi.org/10.29169/1927-5951.2020.10.05.10

(C) 2020 Alfred Maroyi; Licensee SET Publisher.

This is an open access article licensed under the terms of the Creative Commons Attribution Non-Commercial License (http://creativecommons.org/licenses/by-nc/3.0/) which permits unrestricted, non-commercial use, distribution and reproduction in any medium, provided the work is properly cited. 